\title{
Student Cognitive Profile with STEM Based Teaching Material on the Subject of Vibrations and Waves
}

\author{
Rachma Afifah $^{1, a)}$, Ellianawati $^{2, b)}$ \\ ${ }^{1}$ Pendidikan Fisika, Pascasarjana, Universitas Negeri Semarang \\ ${ }^{2}$ Jurusan Fisika Fakultas Matematika dan Ilmu Pengetahuan Alam, Universitas Negeri Semarang \\ 凹: a)rachmafifah@gmail.com, b)ellianawati@mail.unnes.ac.id
}

\begin{abstract}
The results of study Trends in International Mathematics and Science Study (TIMSS) 2011 at the secondary school level showed that the achievement of learning outcomes of Indonesian students in the fields of mathematics and science had not shown satisfactory results. One way to implement effective and enjoyable learning can be supported by teaching materials used in learning. Teaching materials are one of the supporting factors for student learning success. This study aims to produce products and apply teaching materials based on Science, Technology, Engineering, and Mathematics (STEM) to determine the profile of the cognitive process of understanding the concepts of vocational students. The method used in this study is research and development. Characteristics of STEM-based teaching materials that contain material about vibrations and waves associated with STEM aspects and equipped with problems and practical procedures. The results of the analysis of teaching materials can be categorized as feasible, with a percentage of $78.46 \%$. The results of the analysis of student responses after the application of the teaching materials were obtained with a percentage of $83.74 \%$ so that it can be concluded that the teaching material included in the category is very practical to use. The results of the cognitive profile analysis of students' understanding of concepts obtained an interpretation percentage of $76.06 \%$; exemplifying $84.44 \%$; inference $67.78 \%$; comparing $62.59 \%$; explain $59.89 \%$.
\end{abstract}

Keywords: teaching material, STEM, cognitive profile, vibration, wave

\section{INTRODUCTION}

Effective and fun learning will produce quality education. A pleasant atmosphere as an absolute requirement for students to love learning. This is stated in Government Regulation No. 19 of 2005, article 19 paragraph 1 states that: the educational process in the education unit is carried out interactively, inspirational, fun, challenging, motivating students to participate actively and provide sufficient space for initiative, creativity, and independence in accordance with their talents, interests, and physical and psychological development of students.

The learning process that is only centered on the teacher directs students to memorize information, remember and collect much information without being required to understand information and relate it to everyday life. As a result, many graduates are rich in theory, but understanding which develops their potential or the potential that exists in the environment is relatively low. This happens because the concept of understanding is still low though the concepts of physics are mostly obtained from observations and experiments experienced by students. 
Effective and fun learning can be supported by teaching materials used in learning. Teaching materials need to be developed because they can help teachers deliver the material. Sari's research results (2015), which states that the development of teaching materials that have experiential learning content can improve students' understanding of concepts and minds-on. Furthermore, Satriawan \& Rosmiati (2016) stated that the development of contextual-based physics teaching materials by integrating local wisdom can improve the understanding of physics concepts in students for basic physics courses. Then the research of Taqiyyah et al. (2017), proves that teaching materials can improve problem-solving abilities at high criteria with an N-gain of 0.76 .

Science, Technology, Engineering, and Mathematics (STEM) is the integration of the four scientific disciplines (science), technology, engineering, and mathematics in an interdisciplinary approach and is applied based on real-world contexts. According to Becker \& Park (2011), the integration of the STEM approach in teaching and learning may be carried out at all levels of education from elementary school to university. This can be done because aspects of STEM implementation such as intelligence, creativity, and design ability do not depend on age.

Some developed countries such as America and Belgium have tried to improve the ability of the $21^{\text {st }}$ century through the development of Science, Technology, Engineering, and Mathematics (STEM) education. The ability of the 21 st century includes the ability to adapt, think critically, solve problems, self-management, and communicate. According to Bybee (2013), the purpose of the STEM approach is so that students have the literacy skills of science and technology that appear from reading, writing and observing, so that when they enter the community they will be able to develop their competencies to be applied in dealing with the problems of daily life.

STEM brings up many variants to include other disciplines in developing interdisciplinary literacy among students (Copeland et al. 2018). Training on STEM-based learning for teachers can provide insight to adopt innovative and effective learning and act as a guide for students to develop curiosity about science (Siew et al. 2015; Zaniewaki \& Reinholz 2016). Murthi'ik et al. (2018), states that the application of the STEM approach is effective for improving self-efficacy and student learning outcomes.

According to Ejiwale (2013), several obstacles can interfere with the successful implementation of STEM education, namely: (1) poor preparation for providing qualified STEM teachers, (2) lack of investment in professional teacher development, (3) lack of support from the school system, (4) lack of content preparation, (5) lack of collaborative research in the field of STEM, (6) Lack of laboratory facilities and learning media, (7) lack of direct training for students. Referring to the research of Ames et al. (2017) states that physics teachers are the readiest to teach the integrated STEM curriculum.

The integration of STEM learning has five main principles, including the integration of STEM content, problem-based learning, inquiry-based learning, design-based learning, and cooperative learning, (Thibaut et al. 2018). According to Afriana et al. (2016), the application of integrated STEM Project-Based Learning to scientific literacy has increased with an average $\mathrm{N}$-gain of 0.36 and 0.31 in the medium category for knowledge and competency aspects. Furthermore, Utami et al. (2017) state that the development of STEM-A (Science, Technology, Engineering, Mathematics, and Animation) based on local wisdom in learning physics can improve students' understanding of concepts.

The cognitive process profile is the process of changing the ability of perception, memory, thinking, individual understanding of symbols to make reasoning and problem-solving. This cognitive process in its development is influenced by factors heredity, environment, maturity, interests and talents, formation and freedom. There is a study of cognitive profiles by Cahyati (2015) applying the Problem Solving learning model that can improve students' understanding of concepts in Energy Material, where the concept of understanding indicators has the highest $\mathrm{N}$-gain value, which classifies with a value of 0.7 .

Based on the description above, it can be said that STEM teaching and learning materials can improve students' competencies. STEM-based teaching materials are expected to improve the understanding of concepts and student interest in learning. There are several studies on STEM teaching materials including those by Hapiziah et al. (2015) which states the development of effective STEM Problem Based Learning teaching materials with an $\mathrm{N}$-gain of 0.75 . The same thing also expressed by Pangesti et al. (2017) STEM-based teaching materials can increase students' mastery of concept which is characterized by an increase in the value of pretest to posttest. The purpose of this research is to 
produce products and apply teaching materials based on Science, Technology, Engineering, and Mathematics (STEM) to determine the cognitive process profile of the concept of understanding vocational students.

\section{METHODS}

The method used in this research is research and development. The research was conducted at the State Vocational School in Central Java, which is located at Jalan Brotojoyo No. 1, Plombokan, Semarang Utara. The sampling technique is purposive sampling. The large group trial subjects were class XI TKR, amounting to 30 students. The research procedure was divided into four stages, namely preliminary studies, planning, development, and testing of teaching materials.

\section{Data Analysis Technique}

1. Data Analysis of Feasibility Teaching Materials

The developed teaching materials are tested for feasibility by giving an expert feasibility assessment sheet. The feasibility of teaching materials is calculated by finding the percentage using the formula according to (Arikunto, 2013: 272):

$x=\frac{\text { total score }}{\text { maximum number of score }} \times 100 \%$

Following the eligibility criteria for teaching materials presented by Akbar (2016), the eligibility criteria for teaching materials are presented in TABLE 1.

TABLE 1. Classification Feasibility of Teaching Materials

\begin{tabular}{cc}
\hline Score & Level of Feasibility \\
\hline $1 \%<x \leq 50 \%$ & Not Feasible \\
$50 \%<x \leq 70 \%$ & Enough Feasible \\
$70 \%<x \leq 85 \%$ & Feasible \\
$85 \%<x \leq 100 \%$ & Very Feasible \\
\hline
\end{tabular}

2. Data Analysis of Student Response Questionnaire

Providing questionnaires to students on the use of teaching materials in physics learning to see the practicality of teaching materials. The data obtained were analyzed using the following formula:

practical value $=\frac{\text { total score }}{\text { maximum score }} \times 100 \%$

Interpretation criteria for questionnaire scores according to Riduwan (2009) can be seen in TABLE 2.

TABLE 2. Interpretation Criteria for Questionnaire Scores

\begin{tabular}{cc}
\hline Score & Assessment Category \\
\hline $80 \%<\mathrm{x} \leq 100 \%$ & Very Practical \\
$60 \%<\mathrm{x} \leq 80 \%$ & Practical \\
$40 \%<\mathrm{x} \leq 60 \%$ & Enough Practical \\
$20 \%<\mathrm{x} \leq 40 \%$ & Not Practical \\
$0 \%<\mathrm{x} \leq 20 \%$ & Very Impractical \\
\hline
\end{tabular}

3. Cognitive Profile Analysis

The analysis of items was calculated by the score criteria 4 for correct answers. Calculation of percentage profile understanding of concepts by using formulas according to (Arikunto, 2013: 272):

$$
x=\frac{\text { total score }}{\text { maximum number of score }} \times 100 \%
$$




\section{RESULTS AND DISCUSSION}

The product developed in this study was physics teaching material based on STEM material for vibrations and waves for grade XI students of SMK. Based on the results of the analysis of the needs of STEM-based teaching materials on vibration and wave material difficult for students to understand. Teaching materials developed to provide direction for students to explore knowledge and carry out independent activities.

\section{The prototype of Teaching Material Based STEM}

The prototype of STEM-based teaching materials can be seen in TABLE 3.

TABLE 3. The prototype of Teaching Material Based STEM

Teaching material section

Getaran dan Gelombang
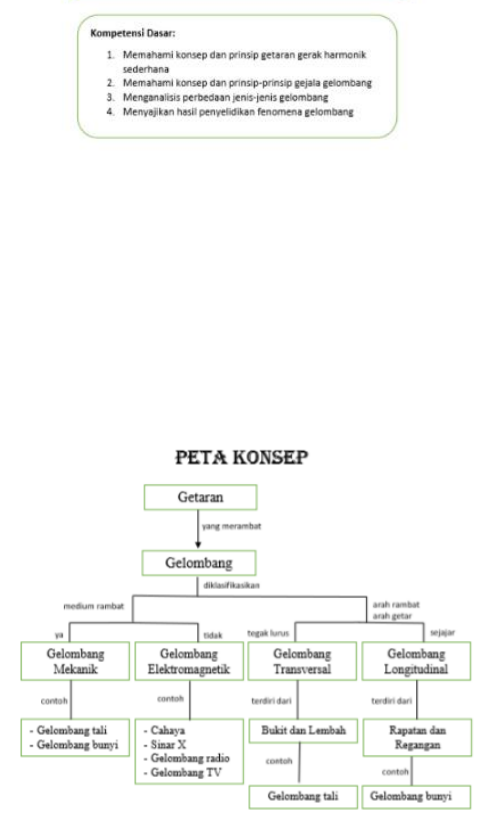

Getaran

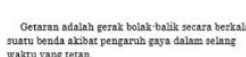

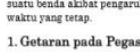

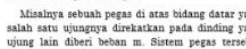

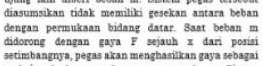

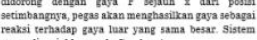

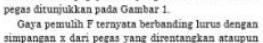

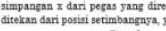

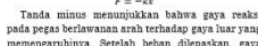

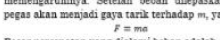

$a=$

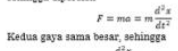

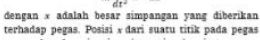

The front cover section of STEMbased teaching materials does not look very interesting, but basic learning competencies are included. The design is indeed too innocent and seems ordinary.

The STEM-based teaching material is also presented with a concept map of what is in the teaching material. The existence of this concept map makes it easier for students to classify an object to be studied.

The section that contains aspects of science is explained in detail about vibrational events complete with spring illustrations. 


\section{Teaching material section}

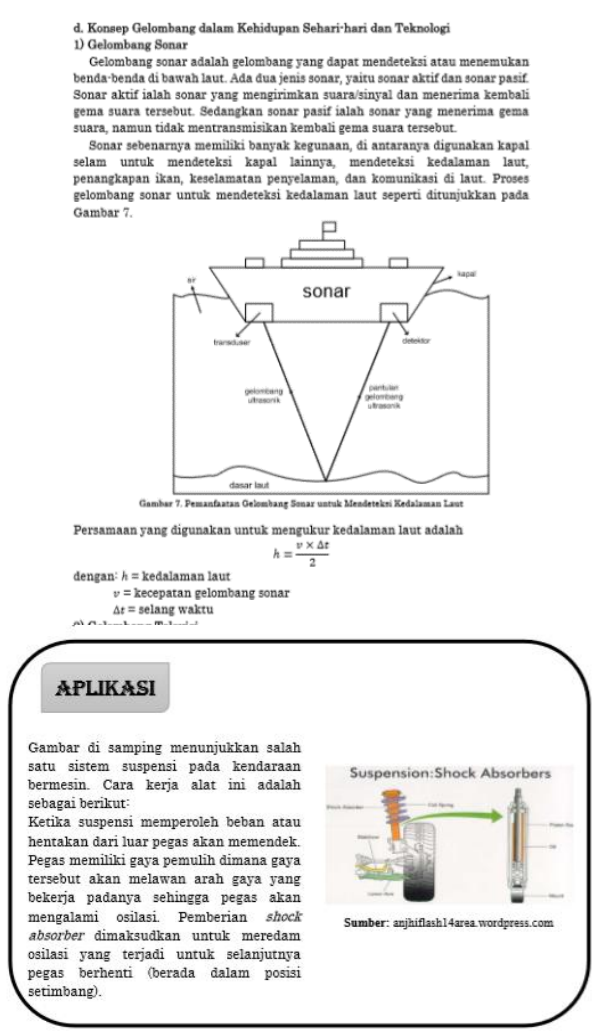

Dari persamaan dapat menurunkan besaran frekuens (f) dan periode $(T)$. Hubungan antara besaran sudut $\omega$, periode $T$, dan frekuensi $f$ adala
\[ \omega=2 \pi f=\frac{2 \pi}{T} \]

Persamaan dapat dituliskan sebagai berikut: $\omega=\sqrt{\frac{k}{m}}$

berarti,

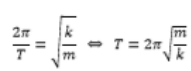
karena $f=\frac{1}{r}$ maka $f=\frac{1}{2 \pi} \sqrt{\frac{k}{m}}$ dengan: $\tau=$ periole getaran pegas dan beban (s) $m=$ massa beban (kg) gas $(\mathrm{N} / \mathrm{m}$ $f=$ frekuensi $(\mathrm{Hz})$

\section{EKSPERIMEN 1}

\section{Tujuan:}

Mampu menjelaskan getaran pada pegas

Alat dan bahan:

1. Pegas

2. Statif

Langkah kerja:

1. Rangkailah pegas dengan beban pada statif

1. Rangkailah pegas dengan beban pada statif!
2. Ukurlah penambahanpanjang pegas setelah diberi beban!

3. Kemudian tarik pegas sejauh $2 \mathrm{~cm}$ dari posisi setimbangnya dan lepaskan!

4. Catat waktu yang diperlukan untuk 10 getaran!

Pertanyaan:

1. Gambarkan sketsa sistem pega

2. Hitunglah periode dan frekuensi getaran!

\section{Explanation}

The section which contains aspects of technology is explained briefly in the description of wave utilization in the field of technology other than sonar waves, there are several other examples described in teaching materials.

The section contains aspects of engineering and is given examples of application techniques in the discussion of vibration, which adds to the knowledge of vocational students about the application of vibration in the automotive field.

The part which contains the mathematics aspect is written clearly and coherently as well as explanations that do not confuse students to understand it.

Contains experimental steps that students can do to better understand the material presented and students can try it independently. 


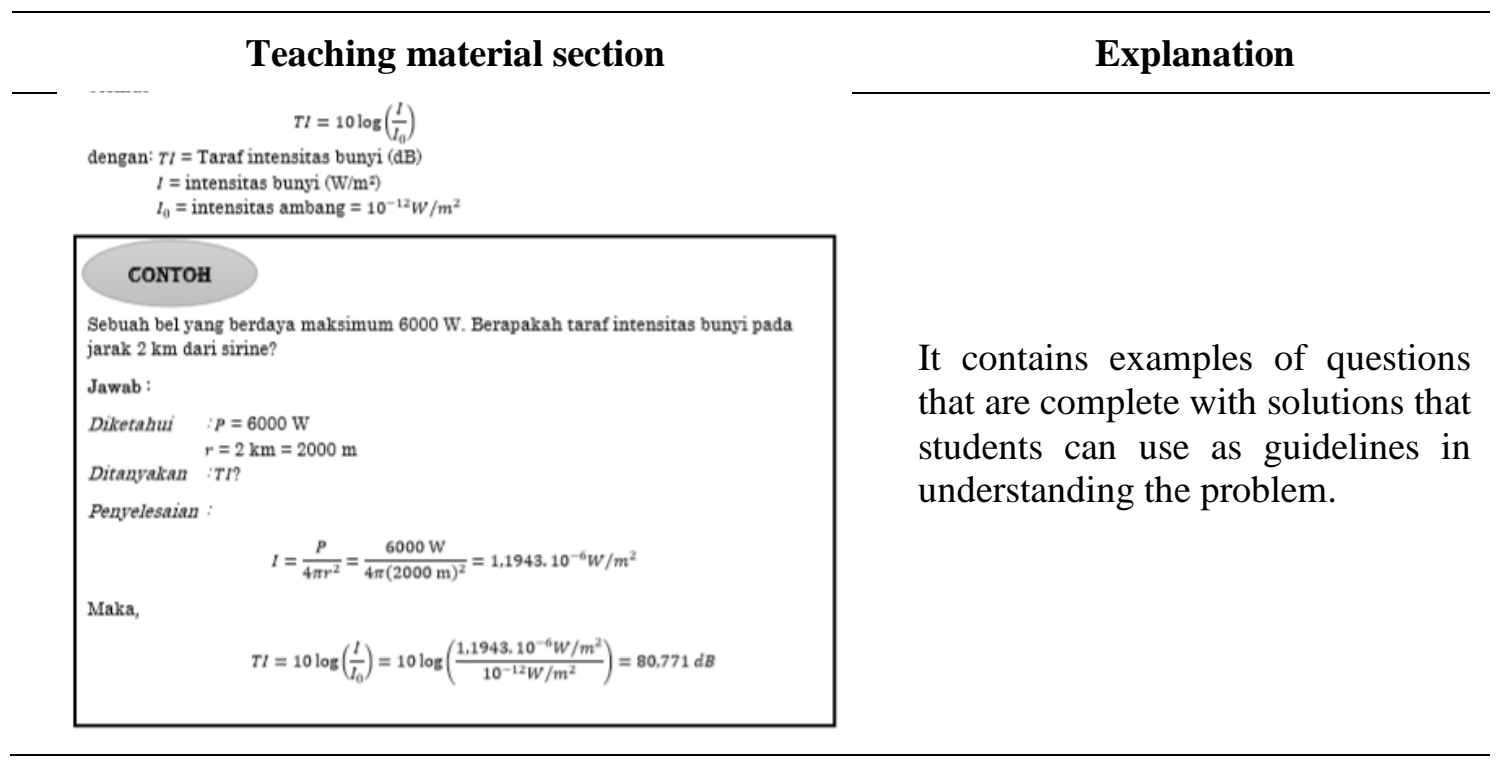

\section{Feasibility of STEM-Based Teaching Materials}

Feasibility of teaching materials in terms of three aspects, namely content, presentation, and language. The results of the feasibility analysis of teaching materials are presented in TABLE 4.

TABLE 4. Results of Feasibility Analysis of STEM-Based Teaching Materials

\begin{tabular}{lcl}
\hline \multicolumn{1}{c}{ Aspect } & Percentage & Criteria \\
\hline Contents & $80.47 \%$ & Feasible \\
Presentation & $78.13 \%$ & Feasible \\
Term & $76.79 \%$ & Feasible \\
Average & $78.46 \%$ & Feasible \\
\hline
\end{tabular}

Based on the results of the feasibility test analysis of STEM-based teaching materials obtained the percentage $r$ has met the aspect of content feasibility consists of elements of conformity, accuracy, and material updating, STEM characteristics, and cognitive profiles. STEM-based teaching materials consistently present material related to vibrations and waves.

\section{Student Response Questionnaire}

Based on the results of the questionnaire analysis of 30 students, the average percentage was $83.74 \%$ with a very practical category.

\section{Students Cognitive Profile}

Cognitive profile analysis is done to find out which indicators are most prominent. The results of the cognitive profile analysis can be seen in FIGURE 1. 


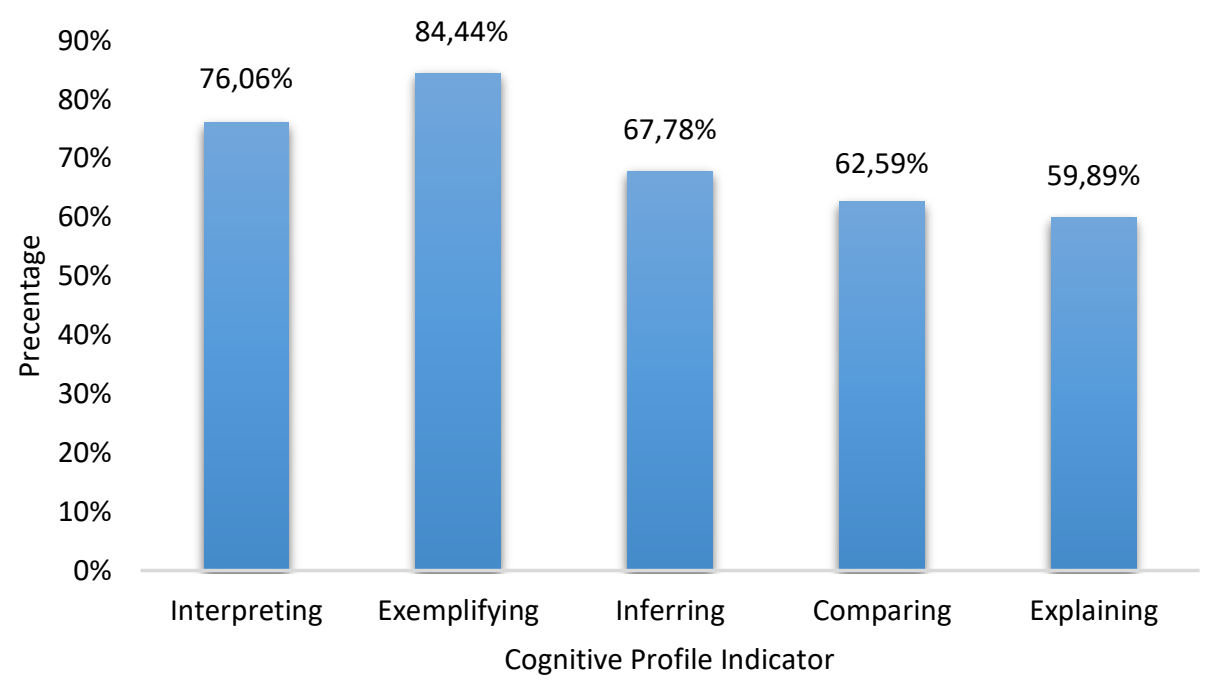

FIGURE 1. Percentage of Student Cognitive Profiles

Based on FIGURE 1, it can be seen that cognitive profile analysis has differences in each indicator. Ability Students' cognitive profiles are measured using delicate instruments in the form of description questions totaling 15 items with each number having a different score depending on the question given. FIGURE 1 presents a comparison of cognitive profiles using STEM-based teaching materials. Indicators of cognitive profile understanding of concepts used as references are indicators of cognitive profile understanding of concepts according to Anderson's taxonomy namely interpretation, example, inference, comparing, and explaining. For indicators to characterize and generalize in previous studies already have the highest $\mathrm{N}$-gain value. So that it is not highlighted on the question made for the test.

In line with the research conducted by Basyari (2015) regarding the Application of Levels of Inquiry at the Interactive Demonstration level to Increase Understanding of Simple Concepts for Junior High School Students, it was concluded that indicators of understanding concepts included in the strong criteria of improvement were classifying. Then the research conducted by Cahyati (2015) applying the Problem Solving learning model can improve the understanding of students' concepts in Energy Material, where indicators of concept understanding have the highest $\mathrm{N}$-gain value, namely classifying with a value of 0.7 .

Cognitive profiles on indicators with lower percentages I highlight in the matter of comparing and explaining. Based on FIGURE 1. the results of cognitive profile analysis obtained the highest percentage in the indicator exemplifying $84.44 \%$. On the test questions given, there is only 1 question in the indicator exemplifying and as many as 27 students work even though there are 4 students the value is not optimal, while 3 students do not work. So it can be concluded that almost all students can answer the questions on the indicator exemplifying well.

\section{SUMMARY}

Based on the results of the study obtained several conclusions that the STEM-based teaching material contains material about vibrations and waves. The results of the analysis of teaching materials can be categorized as feasible with a percentage of $78.46 \%$. The results of the analysis of student responses after applied teaching materials obtained a percentage of $83.74 \%$ so that it can be concluded that the teaching material included in the category is very practical to use. The results of the cognitive profile analysis of students' conceptual understanding obtained the interpretation percentage of 76.06\%; exemplifying $84.44 \%$; inference $67.78 \%$; comparing $62.59 \%$; explain $59.89 \%$. Suggestions that can be given for further research are the need for more material related to technology and engineering to enrich students' knowledge and understanding. 


\section{REFERENCES}

Afriana, J., Permanasari, A., \& Fitriani, A 2016, 'Penerapan Project Based Learning Terintegrasi STEM untuk Meningkatkan Literasi Sains Siswa Ditinjau dari Gender', Jurnal Inovasi Pendidikan IPA, vol. 2, no. 2, pp. 201-212.

Ames, T., Reeve, E., Stewardson, G., \& Lott, K 2017, 'Wanted for $21^{\text {st }}$ Century Schools: Renaissance STEM Teacher Preferred', Journal of Technology Education, vol. 28, no. 2, pp. 19-30.

Arikunto, S 2013, 'Dasar-Dasar Evaluasi Pendidikan Edisi 2', Jakarta, Bumi Aksara.

Basyari, N 2015, 'Penerapan Levels of Inquiry pada Tingkat Interactive Demonstrasion untuk Meningkatkan Pemahaman Konsep Pesawat Sederhana pada Siswa SMP', Skripsi, Universitas Pendidikan Indonesia.

Becker, K., \& Park, K 2011, 'Effects of Integrative Approaches Among Science, Technology, Engineering, and Mathematics (STEM) Subjects on Students' Learning: A Preliminary MetaAnalysis', Journal of STEM Education, vol. 12, no. 5-6, pp. 23-37.

Cahyati, C 2015, 'Penerapan Model Pembelajaran Problem Solving untuk Meningkatkan Pemahaman Konsep Siswa pada Materi Energi', Skripsi, Universitas Pendidikan Indonesia.

Copeland, S., Furlong, M., \& Boroson, B 2018, 'A STE[A]M Approach to Teaching and Learning', International Journal of Teaching and Learning in Higher Education, vol. 30, no. 3, pp. 534-548.

Ejiwale, J 2013, 'Barriers to Successful Implementattion of STEM Education', Journal of Education and Learning, vol. 7, no. 2, pp. 67-74.

Hapiziah, S., Suhery, T., \& Mujamil, J 2015, 'Effects of Integrative Approaches Among Science, Technology, Engineering, and Mathematics (STEM) Subjects on Students' Learning: A Preliminary Meta-Analysis', Journal of STEM Education, vol. 12, no. 5-6, pp. 23-37.

Murthi'ik, I. I., Abdurrahman., \& Rosidin, U 2018, 'The Effectiveness of Applying STEM Approach to Self-Efficacy and Student Learning Outcomes for Teaching Newton's Law', Jurnal Penelitian dan Pengembangan Pendidikan Fisika, vol. 4, no. 1, pp. 11-18.

Pangesti, K. I., Yulianti, D., \& Sugianto 2017, 'Bahan Ajar Berbasis STEM (Science, Technology, Engineering, and Mathematics) untuk Meningkatkan Penguasaan Konsep Siswa SMA', Unnes Physics Education Journal, vol. 6, no. 3, pp. 53-58.

Peraturan Pemerintah Republik Indonesia Nomor 19 Tahun 2005.

Riduwan, 2009, 'Belajar Mudah Penelitian untuk Guru Karyawan dan Peneliti Pemula', Bandung: Alfabeta.

Sari, D. S 2015, 'Pengembangan Bahan Aajar Fisika Berbasis Experiental Learning dalam Meningkatkan Pemahman Konsep dan Minds-on Siswa', Skripsi, FMIPA Universitas Negeri Semarang.

Satriawan, M., \& Rosmiati 2016, 'Pengembangan Bahan Ajar Fisika Berbasis Kontestual dengan Mengintegrasikan Kearifan Lokal untuk Meningkatkan Pemahaman Konsep Siswa pada Mahasiswa', Jurnal Penelitian Pendidikan Sains, vol. 6, no. 1, pp. 1212-1217.

Siew, N. M., Amir, N., \& Chong, C. L 2015, 'The Perceptions of Pre-Service and In-Service Teachers Regarding a Project-Based STEM Approach to Teaching Science', A Springer Open Journal, vol. 4, no. 8, pp. 1-20.

Taqiyyah, S. A., Subali, B \& Handayani, L 2017, 'Implementasi Bahan Ajar Sains Berbahasa Inggris berbasis Metakognitif untuk Meningkatkan Kemampuan Pemecahan Masalah Siswa SMP', Jurnal Inovasi Pendidikan IPA, vol. 3, no. 2, pp. 224-234.

Thibaut, L., Ceuppens, S., Loof, H. D., Meester, J. D., Goovaerts, L., Struyf, A., Pauw, J. B., Dehaene, W., Deprez, J., Cock, M. D., Hellinckx, L., Knipprath, H., Langie, G., Struyven, K., Velde, D. V., 
Petegem, P. V., \& Depaepe, F 2018, 'Integrated STEM Education: A Systematic Review of Instructional Practices in Secondary Education', European Journal of STEM Education, vol. 3, no. 1, pp. 1-12.

Utami, I. S., Septiyanto, R. F., Wibowo, F. C., \& Suryana, A 2017, 'Pengembangan STEM-A (Science, Technology, Engineering, Mathematic and Animation) Berbasis Kearifan Lokal dalam Pembelajaran Fisika', Jurnal Ilmiah Pendidikan Fisika Al-BiRuNi, vol. 6, no. 1, pp. 67-73.

Zaniewski, A. M., \& Reinholz, D 2016, 'Increasing STEM Success: A Near-Peer Mentoring Program in the Physical Sciences', International Journal of STEM Education, vol. 3, no. 14, pp. 1-12. 
